\title{
The adaptive role of cell death in yeast communities stressed with macrolide antifungals
}

\author{
Kireeva N. ${ }^{1}$, Sokolov S.S. ${ }^{2}$, Smirnova E.A. ${ }^{2}$, Galkina K.V. ${ }^{1,2}$, Severin F.F. ${ }^{2}$, \\ Knorre.D.A., ${ }^{1,2 *}$ \\ ${ }^{1}$ Faculty of Bioengineering and Bioinformatics, Moscow State University, Leninskiye Gory 1-73; \\ ${ }^{2}$ Belozersky Institute of Physico-Chemical Biology, Lomonosov Moscow State University, \\ Leninskiye Gory 1-40, Moscow, 119991, Russia
}

\begin{abstract}
Microorganisms cooperate with each other to protect themselves from environmental stressors. An extreme case of such cooperation is regulated cell death for the benefit of other cells. Dying cells can provide surviving cells with nutrients or induce their stress-response by transmitting an alarm signal; however, the role of dead cells in microbial communities is unclear. Here we searched for types of stressors the protection from which can be achieved by death of a subpopulation of cells. Thus, we compared the survival of Saccharomyces cerevisiae cells upon exposure to various stressors in the presence of additionally supplemented living versus dead cells. We found that dead cells contribute to yeast community resistance against macrolide antifungals (e.g. amphotericin B [AmB] and filipin) to a greater extent than living cells. Dead yeast cells absorbed more macrolide filipin than control cells because they exposed intracellular sterol-rich membranes. We also showed that, upon the addition of lethal concentrations of AmB, supplementation with AmB-sensitive cells but not with AmB-resistant cells enabled the survival of wild-type cells. Together, our data suggests that cell-to-cell heterogeneity in sensitivity to AmB can be an adaptive mechanism helping yeast communities to resist macrolides, which are naturally occurring antifungal agents.
\end{abstract}




\section{Importance}

Eukaryotic microorganisms harbour elements of programmed cell death (PCD) mechanisms that are homologous to the PCD of multicellular metazoa. However, it is still debated whether microbial PCD has an adaptive role or the processes of cell death are an aimless operation in self-regulating molecular mechanisms. Here, we demonstrated that dying yeast cells provide an instant benefit for their community by absorbing macrolides, which are bacteria-derived antifungals. Our results illustrate the principle that the death of a microorganism can contribute to the survival of its kin and suggest that early plasma membrane permeabilization improves community-level protection. The latter makes a striking contrast to the manifestations of apoptosis in higher eukaryotes, the process by which plasma membranes maintain integrity.

\section{Introduction}

Microorganisms compete with each other for resources, and the success of this competition depends on their ability to resist toxic compounds produced by the contenders. The resistance can be induced by multiple mechanisms. For example, cells can prevent uptake of toxic inhibitor molecules (1), actively efflux toxic compounds with plasma membrane transporters (2) or metabolise toxic molecules (3). Meanwhile, different mechanisms can cause opposite effects on surrounding cells. On one hand, drug efflux reduces the concentration of the xenobiotic in the cytoplasm, but this does not help neighbouring cells to withstand the stress. On the other hand, if a microorganism decomposes a xenobiotic, it produces a 'common good' by increasing the chances of surrounding cells to survive (see (4) for review). To better exploit these cooperative mechanisms, microbial cells form multicellular aggregates or biofilms. For example, bacterial cells treated with sub-lethal concentrations of antimicrobial peptides induce cell aggregation (5). In yeast, flocculation increases cellular tolerance to macrolide antifungal amphotericin $\mathrm{B}(\mathrm{AmB})$ and hydrogen peroxide, despite that functional flocculin allele FLO11 decreases individual cell fitness (6). Moreover, some yeast strains form colonies with different cell layers, and cells in the exterior layer show increased resistance to environmental stressors (7).

An extreme level of microbial cooperation is 'altruistic' death, a process by which cells die to provide their neighbouring cells with nutritional and environmental conditions 
that support their survival (8-10). The death of some cells in microbial suspension or biofilm can provide an advantage to surviving cells in different ways. For example, it has been shown that cell death in Escherichia coli mediated by the mazF module of maxEF toxin/antitoxin system can prevent the spread of the phages across the bacterial population (11). Moreover, individual $E$. coli cells have different bacterial toxin production rates, so some cells produce more toxins than the others, autolyse and release the toxin to the medium. This toxin inhibits other bacterial strains that lack this toxin/antitoxin system (12). This strategy is considered to be an adaptive manifestation of microbial cell lysis. Furthermore, inviable cells still increase the fitness of their kin by providing them with nutrients $(13,14)$ or transmitting an alarm signal that induces adaptation to stress in surviving cells $(15,16)$. In the case of pathogens, dead cells can modulate the host immune response, thereby preparing a niche for further invasion (17). Finally, dead cells can absorb toxic compounds while allowing surviving cells to continue proliferation (18). Interestingly, it has been shown that dead algae cells absorb pollutants better than living cells (19). Together, this indicates that, although dead cells cannot propagate their genes to offspring, the biochemical processes in their remnants can have a significant effect on the survival of surrounding cells.

Meanwhile, some environmental stressors or xenobiotics induce yeast death that can be prevented by the inhibition of regulatory cascades (20-24). For example, the deletion of metacaspase or endonuclease $\mathrm{G}$ genes, which are homologues of mammalian apoptosis transducers, prevents yeast death induced by oxidative stress $(22,25)$. However, whether this genetically regulated chain of events preceding death has any adaptive role or is just a suboptimal setting of stress-response machinery is unclear.

Here, we proposed that by undergoing cell death, yeast cells can protect their neighbouring cells against some naturally occurring xenobiotics. To test this hypothesis, we screened the effects of a number of xenobiotics and environmental stressors on prototrophic cells while supplementing them with viable or inviable auxotrophic yeast cells. We found that dead yeast cells inhibited the cytotoxic action of macrolide antifungal AmB. Furthermore, supplementation of yeast suspension with an AmB-sensitive strain can increase the average survival of cells in this suspension upon exposure to a high concentration of AmB. Together, our data show that, under certain conditions, decreased xenobiotic resistance in a subpopulation of cells can be beneficial for the microbial community. 


\section{Results}

Some stressors are better tolerated by yeast cells in dense communities than yeast cells less densely dispersed, whereas other stressors kill cells irrespective of the cell suspension density. To distinguish which stressors fall into which category, we subjected prototrophic $(H I S+)$ yeast cells $\left(5 \times 10^{6}\right.$ cell $\left./ \mathrm{ml}\right)$ to various stresses in the absence or presence of histidine auxotrophs (his-). After stress was induced, cell mixtures were transferred to selective yeast nitrogen base (YNB) plates without histidine, where only HIS + cells can grow into a colony. We supplemented HIS+ cells with either living histidine auxotrophs (live aux cells) or inviable histidine auxotrophs (dead aux cells, Figure 1). We performed heat shock to kill the auxotroph cells, because this method does not require additional procedures (e.g. centrifugation) to remove the stressor. Moreover, to assess cell suspension density effects, we tested equal and nine-fold higher cell density of histidine auxotrophs. We selected the concentration of xenobiotics/intensity of environmental stressors so that they kill at least $50 \%$ of $H I S+$ cells under the control conditions, i.e. without the addition of auxotrophic cells.

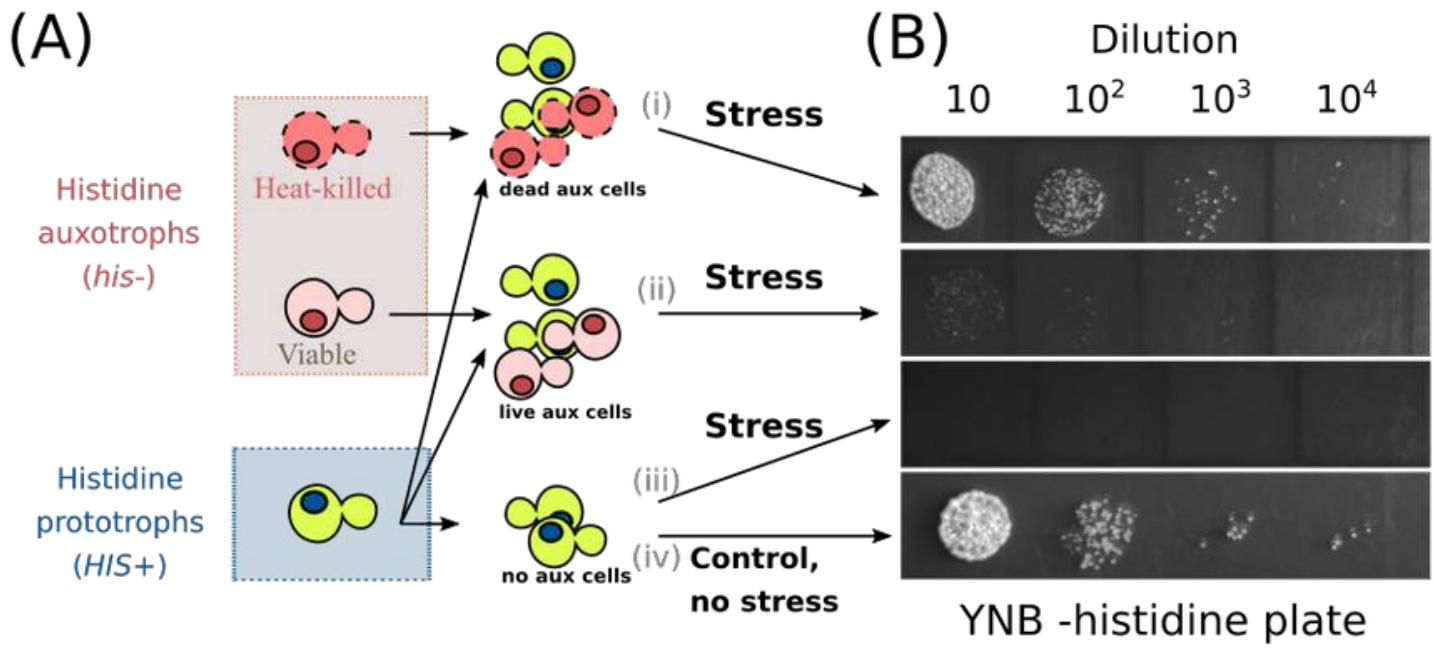

Figure 1. Scheme of experiment to test how an excess of viable and inviable auxotrophic cells alter the survival of prototrophic cells under various stress conditions. (A) Mixtures of (i) histidine auxotrophic (his-) heat shock-killed cells and histidine prototrophic (HIS+) living cells; (ii) histidine auxotrophic ( $h i s-$ ) control cells and histidine prototrophic (HIS+) living cells; (iii) histidine prototrophic living cells were subjected to various stressors and transferred to an YNB-histidine medium plate. Unstressed control cells (iv) were plated before supplementation of stress factors. (B) Representative experiments in which AmB (7 $\mu \mathrm{g} / \mathrm{ml}$ ) was used as the stressor. In a typical experiment, we assessed $4.5 \times 10^{7}$ cells $/ \mathrm{ml}$ auxotrophic cells (his-) and $5 \times 10^{6}$ cells $/ \mathrm{ml}$ prototroph cells $(H I S+)$. 
Supplementation of viable or dead auxotrophic cells in most cases either increased the survival of HIS + cells or had no effect (Figure 2A). We classified stressors depending on how strong the protective effect of dead vs living cells was by clustering the responses of four tested conditions. The analysed types of stressors were clustered into two groups depending on whether the added auxotrophic cells helped the prototrophic cells to survive or not (Figure 2A). Strikingly, supplementation of dead auxotrophic cells protected prototroph yeast cells against macrolide antifungal $\mathrm{AmB}$ much better than an equal concentration of living cells. Stressors were ordered according to the relative effectiveness of the protection achieved by dead or living cells, which revealed that dead auxotrophic cells were the most effective in protecting prototroph from each of the tested AmB concentrations (Figure 2B). At the same time, in our dataset, we found no correlation between the relative efficacy of protection offered by dead cells and the average intensity of the stress (Figure 2C, Figure S1).

Therefore, dead cells specifically increased survival in the case of AmB-induced death rather than increasing stress resistance in general.

To confirm the effect of dead cells on AmB-induced death in independent experiments, we subjected his- yeast cells to heat shock at different intensities. As a result, we obtained yeast suspensions of his- cells with different proportions of viable and inviable cells. We supplemented these his- yeast suspensions to HIS+ cells and assessed the resistance of $H I S+$ cells to AmB. In agreement with the result of our initial survey, the proportion of his- dead cells in the cell suspension correlated with the survival of HIS + cells treated with AmB (Figure 3A). Moreover, dead yeast cells protected yeast suspensions against other macrolide antifungals: filipin, natamycin and nystatin (Figure 3B). 


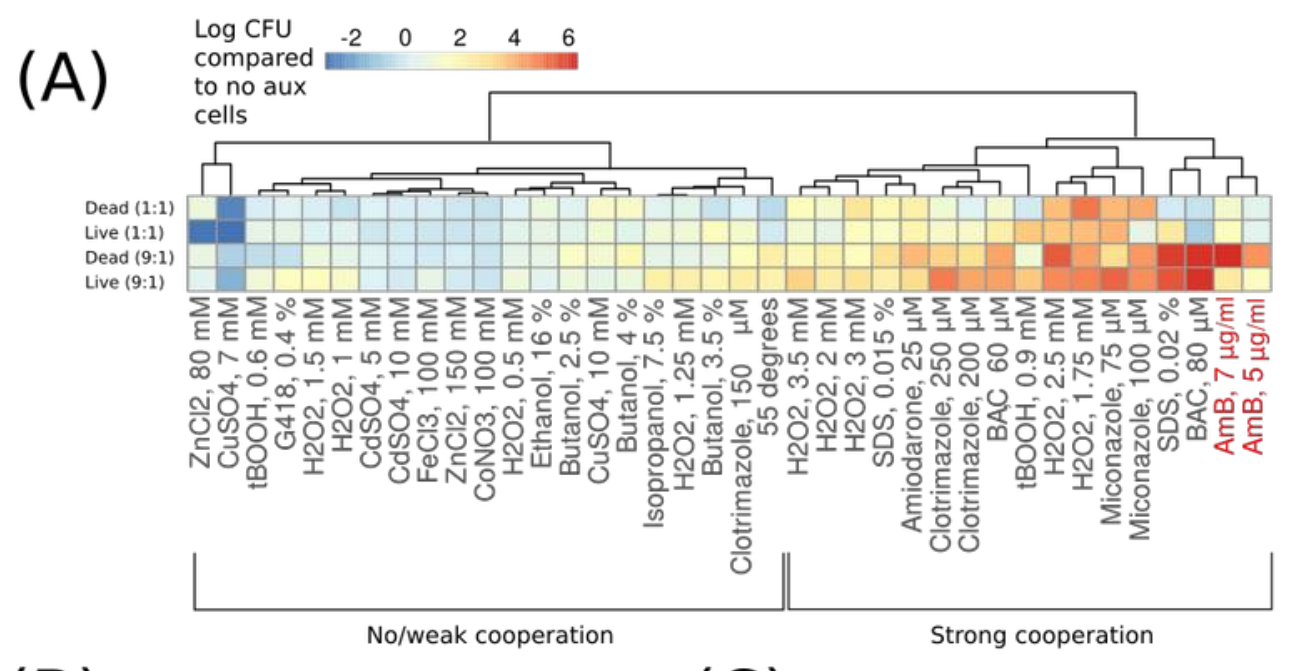

(B)

Protection by dead cells minus protection by live cells,

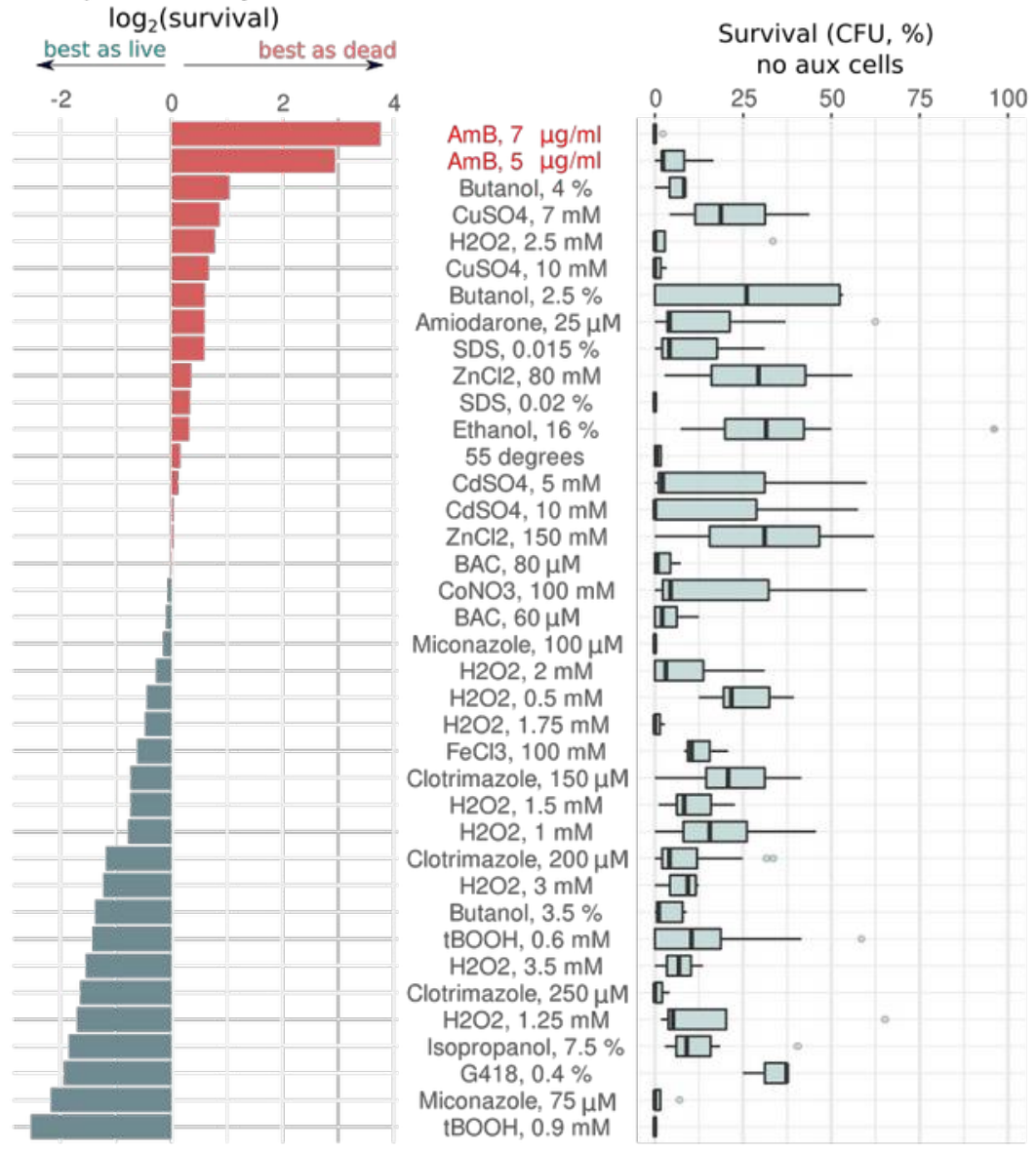

Figure 2. Excess of live and dead yeast cells in the suspension alleviates the lethality of some environmental stressors. (A) Heatmap indicates relative survival of prototrophic yeast cells supplemented with different amounts of living or heat-shock killed auxotrophic cells. (B) Stressors are ranked according to whether dead or living prototroph cells contribute more or less to the survival of the auxotroph's suspension. Zero value indicates equal contribution of dead and living cells to the community stress resistance. (C) The panel shows the survival of prototroph yeast cells under the indicated stress conditions without the addition of auxotrophic cells (no aux cells). 
$(A)$

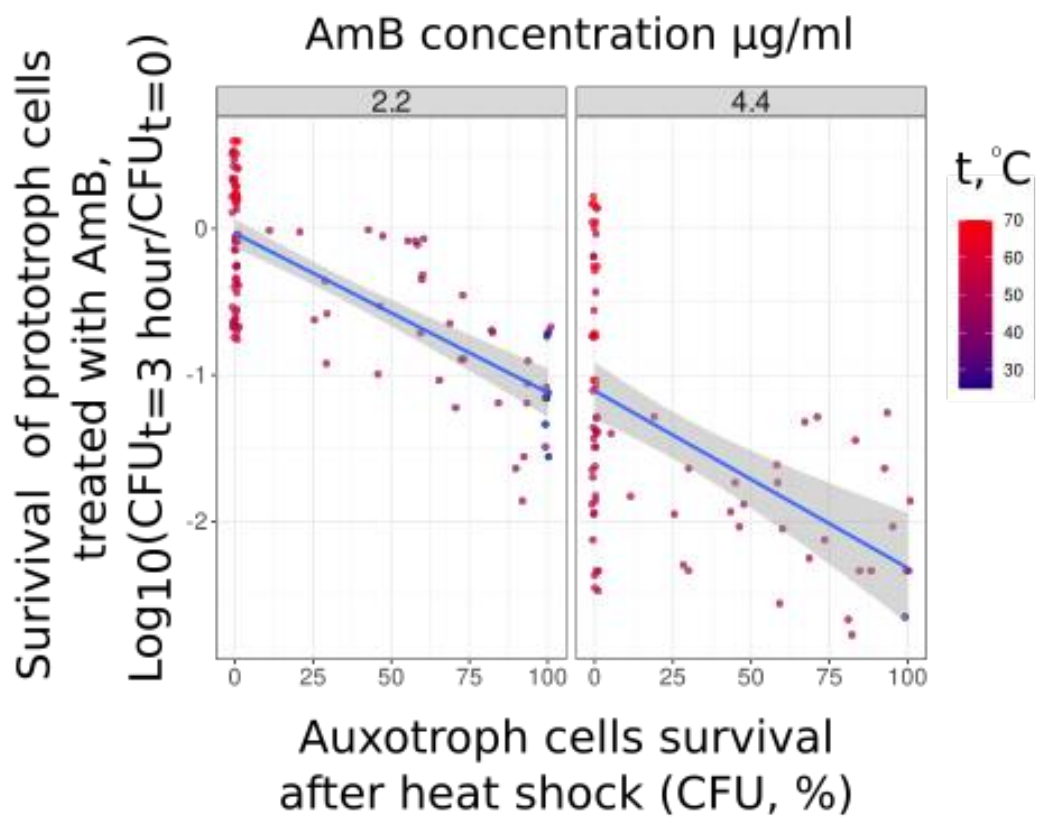

(B)
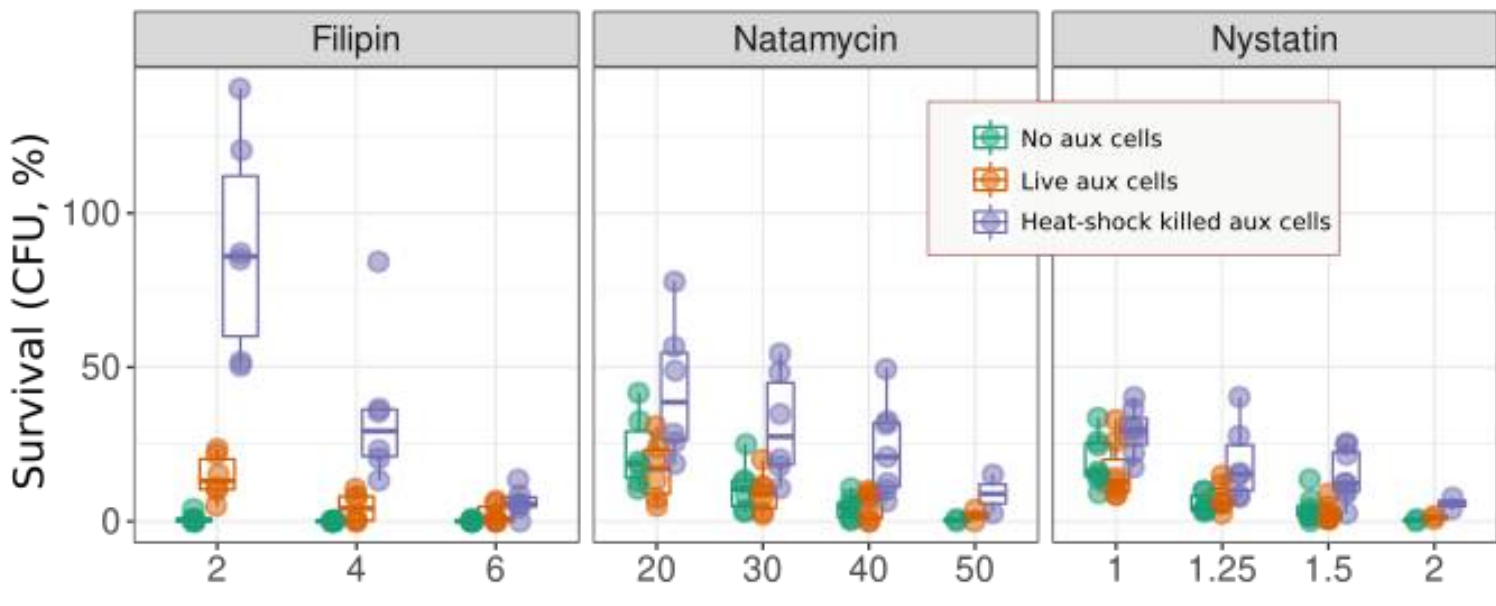

Concentration, $\mu \mathrm{g} / \mathrm{ml}$

Figure 3. Supplementation of dead yeast cells protects yeast suspension against macrolide antifungals better than supplementation of additional living cells. (A)

Protection of prototrophic yeast cells against AmB by auxotrophic cells killed by heat shock of different intensities. The protection provided by heat-shocked auxotrophic yeast cells to prototrophic yeast cells is proportional to the percentage of inviable auxotrophic yeast cells in the suspension. $\left(2.2 \mu \mathrm{g} / \mathrm{ml} \mathrm{AmB}\right.$ : Kendall's tau $=0.54, \mathrm{p}$-value $=1.77 \times 10^{-13} ; 4.4 \mu \mathrm{g} / \mathrm{ml}$ AmB: tau $=0.443 \mathrm{p}$-value $=1.76 \times 10^{-7}$ ); To perform this experiment, we treated auxotrophic (his- or trp-) yeast cells with different temperatures $\left(30^{\circ} \mathrm{C}-70^{\circ} \mathrm{C}\right)$, added them to the corresponding prototrophic $(H I S+$ or $T R P+)$ strain, and then subjected them to AmB for three hours. (B) Supplementation of heat-shock killed cells increased the survival of HIS+ prototrophic cells treated with macrolides: filipin, natamycin and nystatin. 
Given that dead cells showed higher efficiency in protecting remaining surviving cells against macrolides, we reasoned that the supplementation of yeast suspensions with AmBhypersensitive cells could increase the proportion of surviving cells. To test this hypothesis, we tested $\Delta p m p 3$ and $\Delta$ lam1Alam24lam3Alam4 strains that were previously shown to be sensitive to $\mathrm{AmB}(26,27)$. We confirmed that AmB inhibited the growth of these strains at low concentrations, which did not prevent the growth of the parental strains (Figure 4A). Then, we treated yeast suspensions composed of the wild-type histidine prototrophic strain $\left(H I S+\right.$, cell density $2 \times 10^{7}$ cells $\left./ \mathrm{ml}\right)$ and either of these strains. As a control, we supplemented the wild-type histidine prototroph with the parental auxotrophic strain (his-, see the scheme of experimental design in Figure 4B). We additionally supplemented the Llam14lam24lam34lam4 his- cells but not the parental his- control cells that protected the wild-type yeast $H I S+$ strain from a high concentration of AmB (Figure 4C) and filipin (Figure S2). The protection effect increased with the increase in auxotroph cells density. In

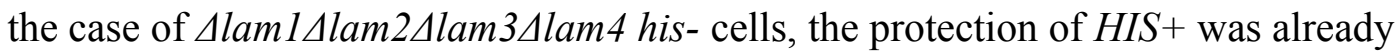
pronounced at a cell density $4 \times 10^{7} . \Delta p m p 3$ his- cells increased AmB-resistance of HIS+ cells when added at a concentration nine times that of $H I S+$ cells (Figure $4 \mathrm{C}, \mathrm{OD}=18$, equivalent of $3.6 \times 10^{8}$ cells) but only marginally. 

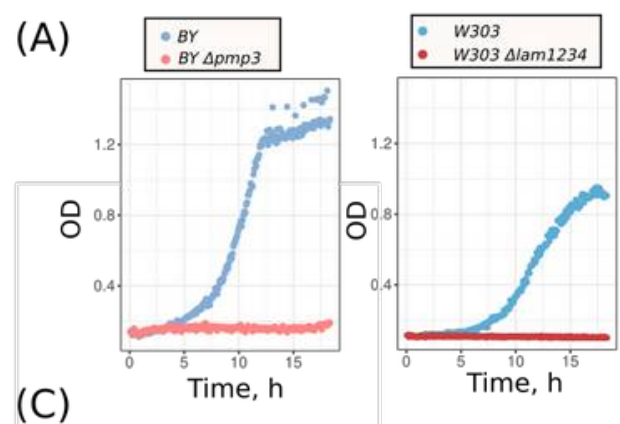

(B)
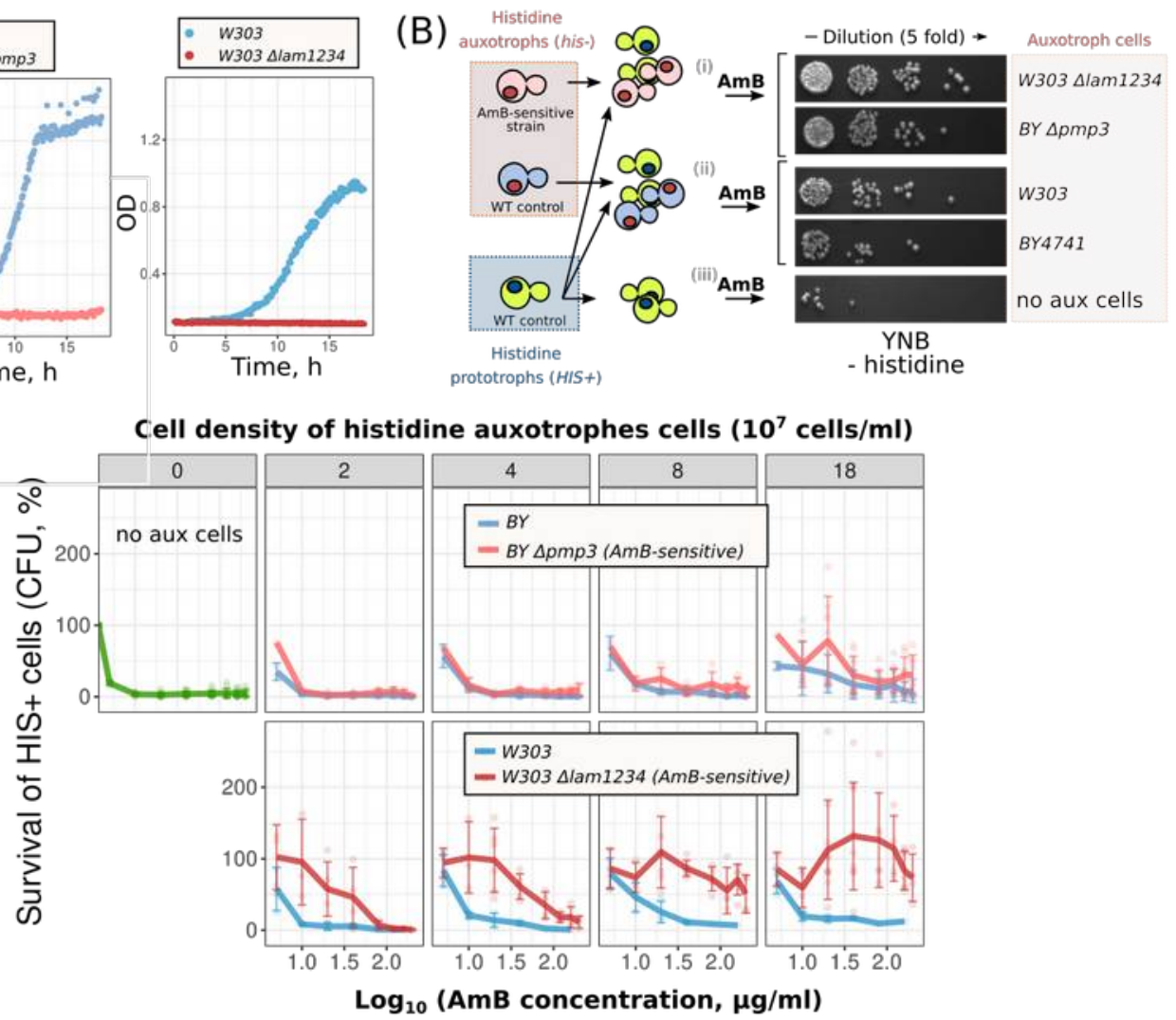

Figure 4. AmB-sensitive cells Alam14lam24lam34lam4 protect wild-type yeast cells from AmB better than the same amount of control cells. (A) Growth of $\Delta p m p 3$, Slam14lam24lam34lam4 (lam1234) and control cells in the presence of AmB $(0.8 \mu \mathrm{g} / \mathrm{ml})$. (B) Scheme of the experiment. (C) Survival of WT HIS+ cells treated with AmB. WT HIS+ cells $2 \times 10^{7}$ cells $/ \mathrm{ml}$ were supplemented with auxotrophic strain either $\Delta p m p 3$ his- or control BY4741 his- cells (upper panel); either Alam14lam24lam34lam4 (lam1234) or W303 control (lower panel). Concentrations of auxotrophic cells are indicated in the upper row of the panel.

Strikingly, we found that the suspension when consisting of equal proportions of

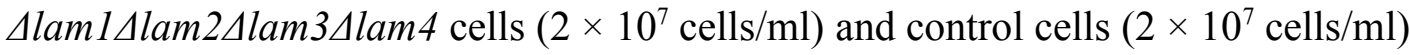
produced more colony-forming units (CFUs) on rich medium than the control cell suspension $\left(4 \times 10^{7}\right.$ cells $\left./ \mathrm{ml}\right)$ if treated with the same concentration of AmB (Figure 5). This result means that each AmB-sensitive cell that was killed by AmB saved more than one control cell with the wild-type AmB resistance. 


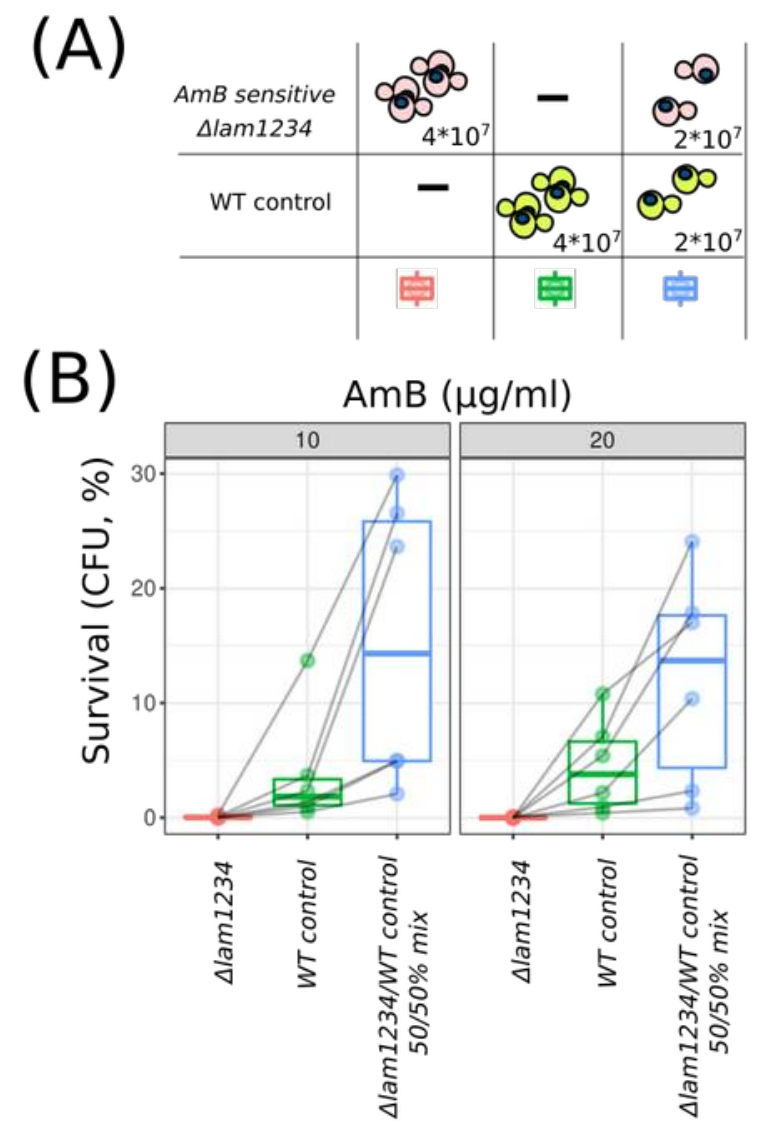

Figure 5. Cell mixture of WT and AmB-sensitive cells survive AmB better than homogenic WT cells. (A) Scheme of the experiment and figure legend. In all cases, we equalised the final concentration of cells in the testing tubes. Numbers designate the final concentration of cells in ml. (B) Average yeast cell survival in the wild-type (W303), $\Delta$ lam1234 and the wild-type/ $\Delta$ lam1234 mixed suspensions treated with 10 or $20 \mu \mathrm{g} / \mathrm{ml}$ of AmB. In these experiments, we assessed cell survival by calculating the number of CFUs in YPD plates after three hours of AmB treatment (e.g. we did not distinguish the strain of surviving cells from the mixed suspensions). Shaded gray lines connect data points from separate day experiments. $P=0.027$ according to paired Wilcoxon signed rank test for a comparison of the wild-type/ $\Delta$ lam1234 mixed suspension with the wild-type suspension.

We tested two possibilities to obtain insight into the mechanisms by which dead cells can protect living cells. First, it was shown earlier that AmB toxicity is mediated by secondary oxidative stress (28) and can be alleviated by the supplementation of antioxidants (29). We suggested that dead cells can release catalase from their cytoplasm into the incubation media and in this way protect living cells from AmB. To test this possibility, we put a genomic copy of cytoplasmic catalase gene CTT1 under the regulation of a $\mathrm{P}_{\mathrm{GAL}}$ promoter (see Materials and Methods) and overexpressed it by growing yeast in a galactose- 
containing medium. $\mathrm{P}_{\mathrm{GAL}}-C T T 1$ trp- catalase overexpression cells showed increased resistance to hydrogen peroxide (Figure 6A) but provided no increase in survival to corresponding prototrophic $T R P 1+$ cells subjected to amphotericin (Figure 6B).
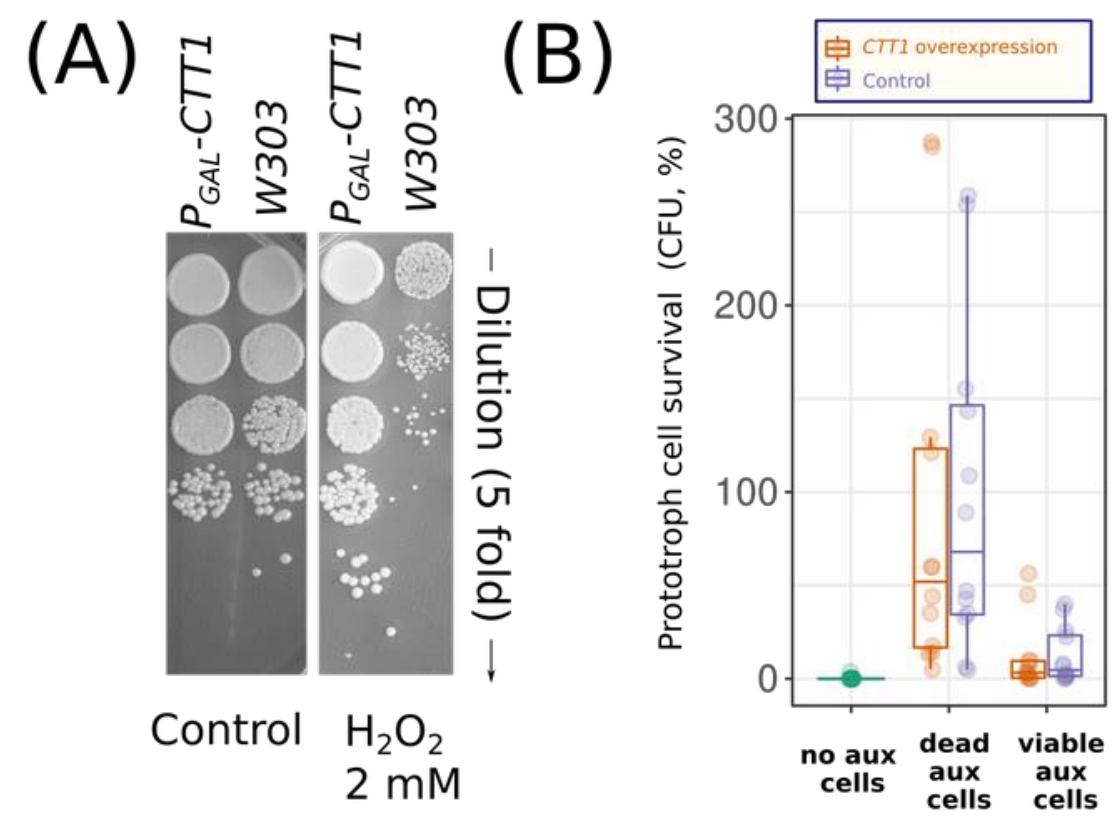

Figure 6. Overexpression of $C T T 1$ in tryptophan auxotrophic cells provides no increase in the survival of TRP1+ cells in the same suspension. (A) Overexpression of CTT1 provides resistance to hydrogen peroxide ( $3 \mathrm{~h}$ incubation times). To increase CTT1 expression, we incubated the $\mathrm{P}_{\mathrm{GAL}}-C T T 1$ strain in galactose-containing rich medium (YPGal) overnight. (B) Experimental design as described in Figure 1 with the only difference being that we used tryptophan selection instead of histidine. Cells were treated with $7 \mu \mathrm{g} / \mathrm{ml} \mathrm{AmB}$; the incubation time with AmB was three hours.

The second possibility we considered was that dead yeast cells absorb macrolide from the medium and, therefore, decrease the amount of antifungals bound to the membranes of living cells. Given that filipin has a high fluorescent yield and binds to sterol-rich membranes, it is a popular reagent to use for visualising sterol-rich membranes in yeast cells $(27,30)$. To test whether inviable yeast cells become permeabilised and absorb more macrolide, we stained the control and heat-shocked killed cells with filipin. Figure 7A shows that while control cells were stained only at the periphery, the heat-shocked cells exhibited intracellular compartment staining. To quantify the absorption of filipin by dead vs living cells, we incubated the yeast suspensions with filipin $(5 \mu \mathrm{g} / \mathrm{ml})$, centrifuged the suspension and measured the residual fluorescence in the supernatant (see Materials and methods section 
for details). The addition of dead cells to a filipin-containing incubation medium decreased the fluorescence in the supernatant (Figure 7B). Suspension of the dead yeast cells (OD $=5$, equal to $10^{8}$ cells $/ \mathrm{ml}$ ) absorbed at an average filipin concentration of $2.55 \mu \mathrm{g} / \mathrm{ml}$. At the same time, the same concentration of living control cells decreased the concentration of filipin in the supernatant by only $0.42 \mu \mathrm{g} / \mathrm{ml}$.

Next, we treated the wild-type cells and Alam14lam24lam34lam4 mutant cells with filipin. In these cells, we analysed filipin intracellular localization. To test the integrity of the plasma membrane, we used propidium iodide, which is commonly used to detect dead cells. Figure $7 \mathrm{C}$ shows that five minutes of treatment of yeasts with filipin induced propidium

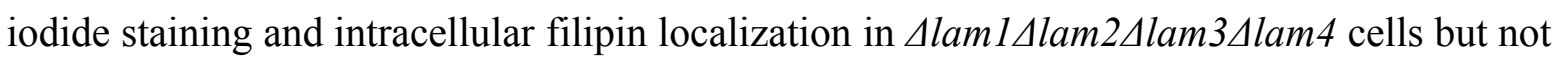
in the control $W 303$ cells.
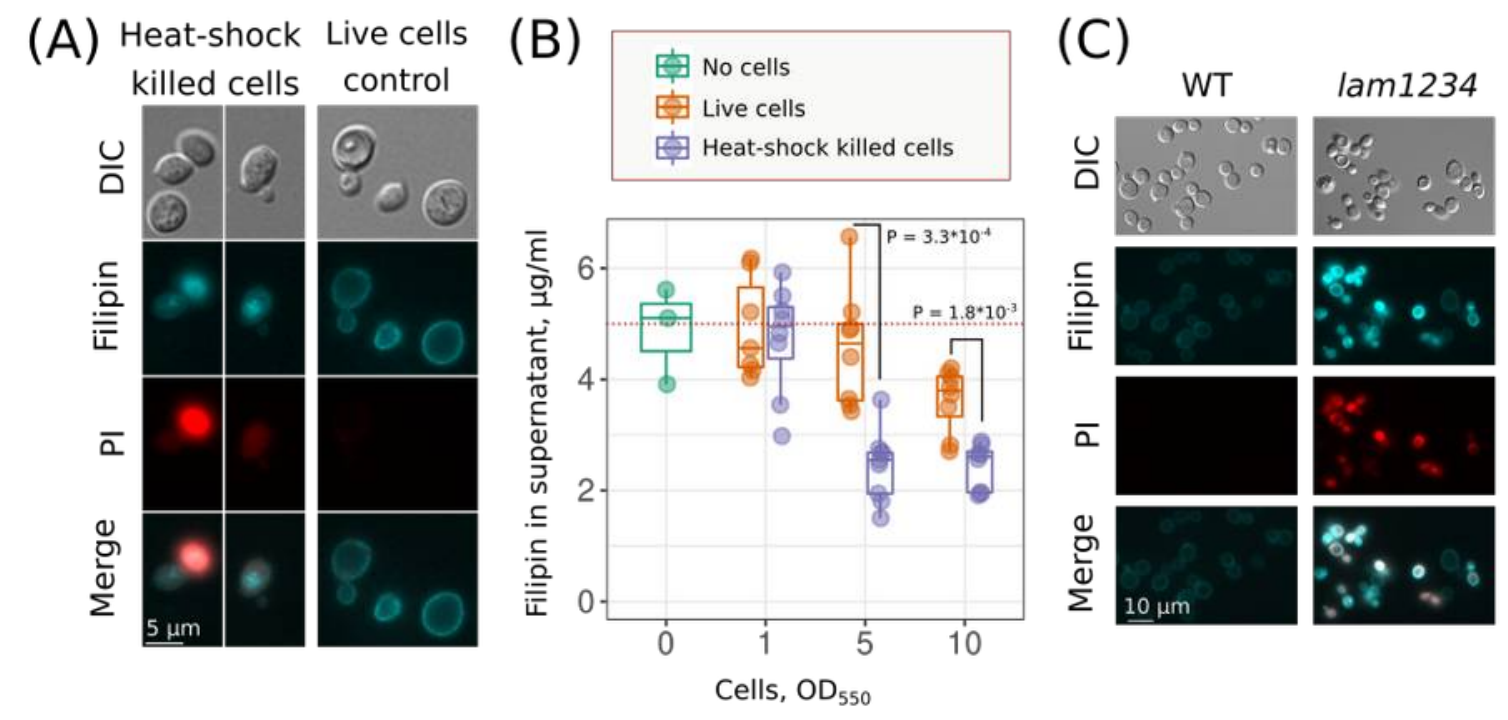

Figure 7. Dead yeast cells absorb macrolide filipin with intracellular compartments. (A) Different localization of the filipin signal in heat-shocked killed and live control cells; (B) Heat-shock killed cells absorb more filipin compared to viable control cells. Suspension of yeast cells was supplemented with filipin $(5 \mu \mathrm{g} / \mathrm{ml})$, then centrifuged. Integral fluorescence spectra in the supernatant were measured. $P$ values were calculated according to the unpaired Mann-Whitney test. (C) Filipin staining induced permeabilization of Slam14lam24lam34lam4 (lam1234) strain but not the wild-type strain. Yeast cells were treated with filipin $(5 \mu \mathrm{g} / \mathrm{ml}$, incubation time 5 minutes). 


\section{Discussion}

Cooperation among neighbouring cells can increase their resistance against some stressors but can be futile against the others. In the case of xenobiotics, hydrophobicity of the molecule is one of the basic factors determining the efficiency of cellular cooperation against it. Indeed, xenobiotics accumulating in cell membranes and lipid droplets can be depleted from media if there are excess cells and limited sources of xenobiotics. Accordingly, our survey of stressors (Figure 2A) showed that supplementation of additional auxotroph cells increased the survival of prototroph cells towards hydrophobic azole antifungals (e.g. miconazole) and surfactants (e.g. BAC) but did not alter their survival in the presence of heavy metals (e.g. $\mathrm{CdSO}_{4}$ ) or fusel alcohols (e.g. butanol). Additional yeast cells in suspensions also increased resistance to high concentrations of hydrogen peroxide (Figure 2A), which was probably due to the contribution of cellular antioxidant systems to the decomposition of hydrogen peroxide.

Meanwhile, we found that only non-viable cells provide significant protection against macrolide antifungals AmB, filipin and, to a lesser extent, natamycin and nystatin (Figures 2B, 3C). All of these compounds are produced by different species of Streptomyces - a widespread gram-positive soil filamentous bacteria (31). The biosynthesis of some of these compounds is species-specific: nystatin ( $S$. noursei), $\operatorname{AmB}(S$. nodosus) and others that are less specific, such as natamycin (32). Macrolide antifungals bind sterol rich membranes, induce their conductance and/or deplete membrane sterol from the membrane while disturbing its vital properties $(33,34)$. The amphiphilic nature of the macrolides suggests that they cannot passively diffuse across the membrane; moreover, cell walls additionally restrain macrolide AmB absorption by yeast cells (35). Therefore, in the suspension of live cells, macrolides interact primarily with the outer leaflet of plasma membranes. Although the plasma membrane contains more sterol than the membranes of other organelles (36), its surface area is much smaller than the integral surface of the cell membranes of permeabilised cells.

Moreover, some studies suggest that sterols are unevenly distributed within plasma membranes, with a major amount of sterol being available only from the inner (cytosol) leaflet of cytosol (37). For example, in yeast, only $20 \%$ of fluorescent dehydroergosterol (DHE) can be quenched by impermeable fluorescent quenchers, as efficient quenching requires the disruption of the plasma membrane integrity (38). Intriguingly, in our recent study, we found that the deletion of sterol-transporting LAM genes increase filipin staining of 
yeast cells in both the plasma membrane and intracellular compartments (27). The high sensitivity of the LAM-deficient strain to filipin (Figure 7C) suggests that intense plasma membrane staining in these experiments can be explained by filipin binding to the inner leaflet of yeast PM rather than an increase in the sterol concentration. Therefore, permeabilization of yeast cells can expose multiple additional macrolide antifungal-binding sites.

Given that permeabilised yeast cells absorb more macrolide antifungals than living yeast cells, a yeast community (e.g. dense suspension or colony) can benefit from early permeabilization of plasma membranes. This occurs in striking contrast to the apoptosis of mammalian cells, which maintains plasma membrane integrity to prevent the release of proinflammatory factors (39). Meanwhile, the metazoa in some cases rely on inflammation upregulation. Accordingly, during pyroptotic cell death of mammalian cells, plasma membrane rupture is facilitated by small plasma membrane proteins gasdermin D (40) and NINJ1 (41). Therefore, we speculate that the physiological scenarios of programmed cell death in yeast should be either homologous or analogous to metazoa programmed cell death mechanisms during early plasma membrane rupture.

Whether clonal microbial populations are heterogeneous is determined by the individual cells' stress resistance phenotype $(42,43)$. This cell-to-cell heterogeneity arises from transcriptional noise, cell cycle-mediated differences and, in the case of budding yeasts, division asymmetry $(44,45)$. An increase in the variance of stress-resistance-phenotypes among individual cells in the population can improve the survival of clonal lineages through repetitive severe stresses (46). Our data extends these observations by exemplifying that improved survival in a suspension can be achieved by an increase in the variance of macrolide tolerance, even if this increase is associated with a decrease in the average tolerance. Indeed, Figures $4 \& 5$ show that the substitution of the control cells in a suspension with AmB-sensitive cells increases overall survival. We suggest that macrolide-resistance heterogeneity can be an adaptive trait that evolves to help cellular clonal communities to withstand a high concentration of macrolides.

\section{Materials and Methods}

Yeast strains, growth medium and reagents. 
We used standard yeast-rich and synthetic mediums described by Sherman (47). Yeast strains used in the study are listed in Table S1. To generate a strain with CTT1 overexpression, we substituted the native CTT1 promoter with a gene cassette containing the $\mathrm{P}_{\mathrm{GAL}}$ promoter and a marker gene. To produce the cassette, we used the polymerase chain reaction (PCR)-based approach described by Longtine et al. (1998) (48) using pFA6aHIS3MX6-PGAL1 plasmid as matrix DNA and the following gene-specific primers: CTT1-F 5'-ctcaatcttgtcgttacttgccettattaaaaaaatccttctcttgtctcgaattcgagctcgtttaaac-3 ', CTT1-R 5 '-ttttaccgaacacgttcatttgtgaagctgagctgattgatcttattggcattttgagatccgggtttt-3'. Primers CTT1-test$F$ 5'-aatgatgagtacgtgcccgat-3' and CTT1-test-R 5'-caccttcaagaggtttaggaa-3' were used to validate the correct clones due to the size of the PCR product.

Experimental setup for studying the contribution of heat-shock killed auxotroph cells to the survival of prototroph living cells

The cells were incubated overnight in 50-ml tubes with $5 \mathrm{ml}$ liquid synthetic medium with all amino acids (YNB complete) at a cell density of 4 to $8 \times 10^{6}$ cells $/ \mathrm{ml}$ (logarithmic growth stage). The cells were collected by centrifugation ( $700 \mathrm{~g}, 5 \mathrm{~min})$, and the medium was replaced with a synthetic medium without histidine (YNB-his). The experiment was performed in a 96-well plate with a cell mixture volume of $200 \mu \mathrm{l}$ per well. We added to each well the cells of prototrophic and auxotrophic strains in one of several combinations: (1) $4 \times$ $10^{6}$ cells $/ \mathrm{ml} H I S+$ control cell; (2) $4 \times 10^{6} H I S+$ cells $/ \mathrm{ml}$ mixed with either live or heat-shock killed cells at $4 \times 10^{6}$ cells $/ \mathrm{ml}$ his- cells (prototrophic: live his- $=1: 1$, prototrophic: dead his$=1: 1)$; (3) $4 \times 10^{6}$ cells $/ \mathrm{ml} H I S+$ cells mixed with either live or heat-shock killed cells at 3.6 $\times 10^{7}$ cells $/ \mathrm{ml}$ his- cells (prototrophic: live his- $=1: 9$, prototrophic: dead his- $=1: 9$ ). Then, xenobiotics or other stress factors were added, and the plate was incubated at $30^{\circ} \mathrm{C}$ and 700 rpm for three hours. Each sample was diluted 75 times and suspended; then, $5 \mu$ of the diluted suspension was transferred onto plates with YNB-his. CFUs were counted in 24-48 hours (see the scheme of the experiment in Figure 1A and experimental results in Figure 2A). Figure 2 includes some experiments performed with four-fold lower cell density. Moreover, in some of the experiments shown in Figure 2, we used the TRP+/trpprototroph/auxotroph pair. 
We did not consider the possibility of histidine or tryptophan auxotrophy reversion in our experiments, given that no single colony had formed in the YNB-his and -trp plates when supplemented with the corresponding prototrophic strain cells.

To generate a set of auxotrophic cells with varying proportions of dead cells, the W303 strain was exposed to different temperatures $\left(30^{\circ} \mathrm{C}-70^{\circ} \mathrm{C}\right)$ for 30 minutes. Auxotrophic cell survival was defined as the ratio of CFUs after to before heat treatment. The set of auxotrophic cells $\left(6 \times 10^{6}\right.$ cells $\left./ \mathrm{ml}\right)$ with varying proportions of dead cells was mixed with exponentially growing prototrophic $(T R P+)$ cells $\left(1.2 \times 10^{6}\right.$ cells $\left./ \mathrm{ml}\right)$. AmB at a concentration of $2.2 \mu \mathrm{g} / \mathrm{ml}$ or $4.4 \mu \mathrm{g} / \mathrm{ml}$ was added to the resulting mixtures; then, the mixtures were incubated for three hours at $30^{\circ} \mathrm{C}$ temperature and $200 \mathrm{rpm}$. The cells of the mixture were transferred onto plates with YNB-trp selective media. CFUs were determined after two days of growth at $30^{\circ} \mathrm{C}$.

\section{Growth kinetics}

Exponentially growing cells were diluted to an optical density of $\mathrm{OD}_{550}=0.2$ and inoculated into a 48 -well plate (Greiner). Plates were incubated at $30^{\circ} \mathrm{C}$ in a spectrophotometer (SpectrostarNANO) with the following settings: orbital shaking at 500 rpm for $30 \mathrm{sec}$ before measurements; $\mathrm{OD}_{550}$ measurements were performed at 5-min intervals.

\section{Fluorescent microscopy}

We resuspended wild-type and mutant yeast cells in $50 \mathrm{mM}$ potassium phosphate buffer to a final concentration $5 \times 10^{7}$ cells $/ \mathrm{ml}$ and supplemented the suspension with filipin (filipin complex from Streptomyces filipinensis; Sigma F9765) to a final concentration of 5 $\mu \mathrm{g} / \mathrm{ml}$. After five minutes of incubation, filipin was removed from the medium by centrifugation and cells were supplemented with propidium iodide (Thermo Fisher Scientific, P3566, final concentration $1 \mu \mathrm{g} / \mathrm{ml}$ ). To photograph cells, we used an Olympus BX41 microscope with a U-MNU2 filter (excitation wavelength 360-370 nm; beam splitter filter 360-370 nm; emission $>420 \mathrm{~nm}$ ) for filipin and U-MNG2 filter (excitation 530-550 nm, beam splitter filter $570 \mathrm{~nm}$; emission $>590 \mathrm{~nm}$ ) for propidium iodide. Photographs were taken with a DP30BW charged-coupled device camera.

Filipin absorption experiments 
Cells were grown overnight on solid YNB complete medium and then resuspended in $50 \mathrm{mM}$ potassium phosphate buffer, $\mathrm{pH} 5.5$, to a final $\mathrm{OD}_{550}$ of 1,5 or 10. Filipin was added to a final concentration of $5 \mu \mathrm{g} / \mathrm{ml}$. After $5 \mathrm{~min}$ incubation, the cells centrifuged and supernatant was transferred to a 96-well plate. Fluorescence of unabsorbed filipin was analysed using Fluoroskan Ascent (excitation $355 \mathrm{~nm}$; emission $460 \mathrm{~nm}$ ). The filipin calibration curve, as shown in Figure S3, revealed the linearity of the tested concentration of filipin.

\section{Data analysis}

We analysed data and generated the figures with R tidyverse libraries (49). A heatmap was generated with the pheatmap R package (version 1.0.12) with default parameters that use maximum linkage clustering. Where possible, we have shown individual data points and provided connections between data points obtained from the same experiment.

\section{Funding}

The study was supported by the Russian Foundation for Basic Research grant N 18 04-01183 (Figures 1-2) and the Russian Science Foundation grant N 18-14-00151 (Figures 37).

\section{Acknowledgements}

We are grateful to Emir Radkevich, who participated in some of the preliminary experiments of this project. We are grateful to the G. F. Gause Institute of New Antibiotics, Moscow, Russian Federation, for providing us with nystatin. This research has been supported by the Interdisciplinary Scientific and Educational School of Moscow University Molecular Technologies of the Living Systems and Synthetic Biology.

\section{References}

1. Denyer SP, Maillard JY. 2002. Cellular impermeability and uptake of biocides and antibiotics in gram-negative bacteria. Symp Ser Soc Appl Microbiol 35S-45S.

2. Cannon RD, Lamping E, Holmes AR, Niimi K, Baret PV, Keniya MV, Tanabe K, Niimi M, Goffeau A, Monk BC. 2009. Efflux-mediated antifungal drug resistance. Clin Microbiol Rev 22:291-321.

3. Bush K, Bradford PA. 2019. Interplay between $\beta$-lactamases and new $\beta$-lactamase inhibitors. Nat Rev Microbiol 17:295-306. 
4. Wloch-Salamon DM. 2014. Sociobiology of the budding yeast. J Biosci 39:225-236.

5. Rodríguez-Rojas A, Baeder DY, Johnston P, Regoes RR, Rolff J. 2021. Bacteria primed by antimicrobial peptides develop tolerance and persist. PLoS Pathog 17:e1009443.

6. Smukalla S, Caldara M, Pochet N, Beauvais A, Guadagnini S, Yan C, Vinces MD, Jansen A, Prevost MC, Latgé J-P, Fink GR, Foster KR, Verstrepen KJ. 2008. FLO1 is a variable green beard gene that drives biofilm-like cooperation in budding yeast. Cell 135:726-737.

7. Cáp M, Stěpánek L, Harant K, Váchová L, Palková Z. 2012. Cell differentiation within a yeast colony: metabolic and regulatory parallels with a tumor-affected organism. Mol Cell 46:436-448.

8. Allocati N, Masulli M, Di Ilio C, De Laurenzi V. 2015. Die for the community: an overview of programmed cell death in bacteria. Cell Death Dis 6:e1609.

9. Hardwick JM. 2018. Do Fungi Undergo Apoptosis-Like Programmed Cell Death? MBio 9.

10. Smith RP, Barraza I, Quinn RJ, Fortoul MC. 2020. The mechanisms and cell signaling pathways of programmed cell death in the bacterial world. Int Rev Cell Mol Biol 352:1-53.

11. Hazan R, Engelberg-Kulka H. 2004. Escherichia coli mazEF-mediated cell death as a defense mechanism that inhibits the spread of phage P1. Mol Genet Genomics 272:227-234.

12. Mavridou DAI, Gonzalez D, Kim W, West SA, Foster KR. 2018. Bacteria Use Collective Behavior to Generate Diverse Combat Strategies. Curr Biol 28:345-355.e4.

13. Herker E, Jungwirth H, Lehmann KA, Maldener C, Fröhlich K-U, Wissing S, Büttner S, Fehr M, Sigrist S, Madeo F. 2004. Chronological aging leads to apoptosis in yeast. J Cell Biol 164:501-507.

14. Muñoz-Dorado J, Marcos-Torres FJ, García-Bravo E, Moraleda-Muñoz A, Pérez J. 2016. Myxobacteria: Moving, Killing, Feeding, and Surviving Together. Front Microbiol 7:781.

15. Rowbury RJ. 2001. Cross-talk involving extracellular sensors and extracellular alarmones gives early warning to unstressed Escherichia coli of impending lethal chemical stress and leads to induction of tolerance responses. J Appl Microbiol 90:677-695.

16. Bhattacharyya S, Walker DM, Harshey RM. 2020. Dead cells release a "necrosignal" that activates antibiotic survival pathways in bacterial swarms. Nat Commun 11:4157.

17. Ackermann M, Stecher B, Freed NE, Songhet P, Hardt W-D, Doebeli M. 2008. Selfdestructive cooperation mediated by phenotypic noise. Nature 454:987-990.

18. Snoussi M, Talledo JP, Del Rosario N-A, Mohammadi S, Ha B-Y, Košmrlj A, Taheri-Araghi S. 2018. Heterogeneous absorption of antimicrobial peptide LL37 in Escherichia coli cells enhances population survivability. Elife 7:e38174.

19. Tam NFY, Chong AMY, Wong YS. 2002. Removal of tributyltin (TBT) by live and dead microalgal cells. Mar Pollut Bull 45:362-371.

20. Ludovico P, Sousa MJ, Silva MT, Leão CL, Côrte-Real M. 2001. Saccharomyces cerevisiae commits to a programmed cell death process in response to acetic acid. Microbiology 147:2409-2415.

21. Ludovico P, Rodrigues F, Almeida A, Silva MT, Barrientos A, Côrte-Real M. 2002. 
Cytochrome c release and mitochondria involvement in programmed cell death induced by acetic acid in Saccharomyces cerevisiae. Mol Biol Cell 13:2598-2606.

22. Madeo F, Herker E, Maldener C, Wissing S, Lächelt S, Herlan M, Fehr M, Lauber K, Sigrist SJ, Wesselborg S, Fröhlich KU. 2002. A caspase-related protease regulates apoptosis in yeast. Mol Cell 9:911-917.

23. Pozniakovsky AI, Knorre DA, Markova OV, Hyman AA, Skulachev VP, Severin FF. 2005. Role of mitochondria in the pheromone- and amiodarone-induced programmed death of yeast. J Cell Biol 168:257-269.

24. Büttner S, Eisenberg T, Herker E, Carmona-Gutierrez D, Kroemer G, Madeo F. 2006. Why yeast cells can undergo apoptosis: death in times of peace, love, and war. J Cell Biol 175:521-525.

25. Büttner S, Eisenberg T, Carmona-Gutierrez D, Ruli D, Knauer H, Ruckenstuhl C, Sigrist C, Wissing S, Kollroser M, Fröhlich K-U, Sigrist S, Madeo F. 2007. Endonuclease G regulates budding yeast life and death. Mol Cell 25:233-246.

26. Huang Z, Chen K, Zhang J, Li Y, Wang H, Cui D, Tang J, Liu Y, Shi X, Li W, Liu D, Chen R, Sucgang RS, Pan X. 2013. A functional variomics tool for discovering drugresistance genes and drug targets. Cell Rep 3:577-585.

27. Sokolov SS, Vorobeva MA, Smirnova AI, Smirnova EA, Trushina NI, Galkina KV, Severin FF, Knorre DA. 2020. LAM Genes Contribute to Environmental Stress Tolerance but Sensibilize Yeast Cells to Azoles. Front Microbiol 11:38.

28. Mesa-Arango AC, Trevijano-Contador N, Román E, Sánchez-Fresneda R, Casas C, Herrero E, Argüelles JC, Pla J, Cuenca-Estrella M, Zaragoza O. 2014. The production of reactive oxygen species is a universal action mechanism of Amphotericin B against pathogenic yeasts and contributes to the fungicidal effect of this drug. Antimicrob Agents Chemother 58:6627-6638.

29. Blatzer M, Jukic E, Posch W, Schöpf B, Binder U, Steger M, Blum G, Hackl H, Gnaiger E, Lass-Flörl C, Wilflingseder D. 2015. Amphotericin B Resistance in Aspergillus terreus Is Overpowered by Coapplication of Pro-oxidants. Antioxid Redox Signal 23:1424-1438.

30. Grossmann G, Opekarová M, Malinsky J, Weig-Meckl I, Tanner W. 2007. Membrane potential governs lateral segregation of plasma membrane proteins and lipids in yeast. EMBO J $26: 1-8$.

31. Caffrey P, De Poire E, Sheehan J, Sweeney P. 2016. Polyene macrolide biosynthesis in streptomycetes and related bacteria: recent advances from genome sequencing and experimental studies. Appl Microbiol Biotechnol 100:3893-3908.

32. Aparicio JF, Barreales EG, Payero TD, Vicente CM, de Pedro A, Santos-Aberturas J. 2016. Biotechnological production and application of the antibiotic pimaricin: biosynthesis and its regulation. Appl Microbiol Biotechnol 100:61-78.

33. Kristanc L, Božič B, Jokhadar ŠZ, Dolenc MS, Gomišček G. 2019. The pore-forming action of polyenes: From model membranes to living organisms. Biochim Biophys Acta Biomembr 1861:418-430.

34. Carolus H, Pierson S, Lagrou K, Van Dijck P. 2020. Amphotericin B and Other Polyenes-Discovery, Clinical Use, Mode of Action and Drug Resistance. J Fungi (Basel) 6.

35. Ellul H, Beezer AE, Brain AP, Miles RJ, Sivayogan SR. 1985. The effect of chemical 
modification of Saccharomyces cerevisiae on electrophoretic mobility, cell-wall structure and amphotericin B uptake. Biochim Biophys Acta 845:151-157.

36. Tuller G, Nemec T, Hrastnik C, Daum G. 1999. Lipid composition of subcellular membranes of an FY1679-derived haploid yeast wild-type strain grown on different carbon sources. Yeast 15:1555-1564.

37. Courtney KC, Pezeshkian W, Raghupathy R, Zhang C, Darbyson A, Ipsen JH, Ford DA, Khandelia H, Presley JF, Zha X. 2018. C24 Sphingolipids Govern the Transbilayer Asymmetry of Cholesterol and Lateral Organization of Model and Live-Cell Plasma Membranes. Cell Rep 24:1037-1049.

38. Solanko LM, Sullivan DP, Sere YY, Szomek M, Lunding A, Solanko KA, Pizovic A, Stanchev LD, Pomorski TG, Menon AK, Wüstner D. 2018. Ergosterol is mainly located in the cytoplasmic leaflet of the yeast plasma membrane. Traffic 19:198-214.

39. Zhang Y, Chen X, Gueydan C, Han J. 2018. Plasma membrane changes during programmed cell deaths. Cell Res 28:9-21.

40. Shi J, Zhao Y, Wang K, Shi X, Wang Y, Huang H, Zhuang Y, Cai T, Wang F, Shao F. 2015. Cleavage of GSDMD by inflammatory caspases determines pyroptotic cell death. Nature 526:660-665.

41. Kayagaki N, Kornfeld OS, Lee BL, Stowe IB, O'Rourke K, Li Q, Sandoval W, Yan D, Kang J, Xu M, Zhang J, Lee WP, McKenzie BS, Ulas G, Payandeh J, Roose-Girma M, Modrusan Z, Reja R, Sagolla M, Webster JD, Cho V, Andrews TD, Morris LX, Miosge LA, Goodnow CC, Bertram EM, Dixit VM. 2021. NINJ1 mediates plasma membrane rupture during lytic cell death. Nature 591:131-136.

42. Levy SF, Ziv N, Siegal ML. 2012. Bet hedging in yeast by heterogeneous, agecorrelated expression of a stress protectant. PLoS Biol 10:e1001325.

43. Attfield PV, Choi HY, Veal DA, Bell PJ. 2001. Heterogeneity of stress gene expression and stress resistance among individual cells of Saccharomyces cerevisiae. Mol Microbiol 40:1000-1008.

44. Ackermann M. 2015. A functional perspective on phenotypic heterogeneity in microorganisms. Nat Rev Microbiol 13:497-508.

45. Knorre DA, Azbarova AV, Galkina KV, Feniouk BA, Severin FF. 2018. Replicative aging as a source of cell heterogeneity in budding yeast. Mech Ageing Dev 176:24-31.

46. Holland SL, Reader T, Dyer PS, Avery SV. 2014. Phenotypic heterogeneity is a selected trait in natural yeast populations subject to environmental stress. Environ Microbiol 16:1729-1740.

47. Sherman F. 2002. Getting started with yeast. Methods Enzymol 350:3-41.

48. Longtine MS, McKenzie A 3rd, Demarini DJ, Shah NG, Wach A, Brachat A, Philippsen P, Pringle JR. 1998. Additional modules for versatile and economical PCR-based gene deletion and modification in Saccharomyces cerevisiae. Yeast 14:953-961.

49. Wickham H, Averick M, Bryan J, Chang W, McGowan L, François R, Grolemund G, Hayes A, Henry L, Hester J, Kuhn M, Pedersen T, Miller E, Bache S, Müller K, Ooms J, Robinson D, Seidel D, Spinu V, Takahashi K, Vaughan D, Wilke C, Woo K, Yutani H. 2019. Welcome to the tidyverse. J Open Source Softw 4:1686. 
50. Galkina KV, Finkelberg JM, Markova OV, Azbarova AV, Banerjee A, Kumari S, Sokolov SS, Severin FF, Prasad R, Knorre DA. 2020. Protonophore FCCP provides fitness advantage to PDR-deficient yeast cells. J Bioenerg Biomembr 52:383-395. 